\title{
e-Health and Primary Care in Brazil: concepts, correlations and trends
}

\author{
e-Saúde e Atenção Primária no Brasil: conceitos, correlações e tendências \\ e-Salud y Atención Primaria en Brasil: conceptos, tendencias y correlaciones
}

\author{
Gustavo de Araújo Porto Landsberg. Centro de Inovação Unimed-BH. Belo Horizonte, MG, Brasil. landsberg@ primaria.life \\ (Corresponding author)
}

\begin{abstract}
Objetive: This paper aims to discuss e-Health and Primary Care concepts and correlations, considering current context of healthcare and health information technology in Brazil. Methods: Conceptual literature regarding to Primary Care and health information technology was selected and discussed. Results: Brazilian public health system has delivered cost-effective primary care over the last 20 years and recently a similar movement is being observed at private sector. Additionally, there is a expanding adoption of health information technology, which resources can be use to develop all core attributes of Primary Care. Conclusions: The e-Health utilization in Primary Care has potencial to improve health and reduce costs. A clear specific national policy, broad discussion over current regulation and a closer relationship between health professionals and information technology developers are needed to offer cost-effective e-Health aligned to Primary Care atributes.
\end{abstract}

\section{Resumo}

Objetivo: Este artigo tem como objetivo discutir os conceitos de e-Saúde e Atenção Primária à Saúde (APS) e suas correlações, considerando o contexto atual da tecnologia da informação para saúde e da assistência à saúde no Brasil. Métodos: Literatura conceitual sobre a APS e tecnologia da informação para saúde foi selecionada e discutida. Resultados: O sistema público de saúde (SUS) tem entregue uma Atenção Primária custo-efetiva nos últimos 20 anos e, recentemente, um movimento semelhante está sendo observado no setor privado. Além disso, há uma crescente adoção de tecnologia da informação na saúde, cujos recursos podem ser usados para desenvolver todos os atributos essenciais da APS. Conclusões: A utilização da e-Saúde na APS tem potencial para melhorar a saúde e reduzir os custos. Uma política nacional clara e específica, um amplo debate sobre a regulamentação atual e uma relação mais estreita entre os profissionais de saúde e desenvolvedores de tecnologia da informação são necessários para oferecer e-Saúde custo-eficaz alinhada com atributos essenciais da atenção primária.

\section{Resumen}

Objetivo: Este artículo tiene el objetivo de discutir los conceptos de Atención Primaria de Salud (APS) y e-Salud y sus correlaciones, considerando el contexto de la tecnología de la información para salud y de la asistencia a salud en Brasil. Métodos: Literatura conceptual acerca de la tecnología de la Información para la Salud y Atención Primaria de Salud fue seleccionada y discutida. Resultados: El sistema público de salud brasileño (SUS) ha ofertado Atención Primaria costo-efectiva en los últimos 20 años y ahora se observa un movimiento similar en el sector privado. Además, la cresciente adopción de la tecnología de la información para la salud, cuyos recursos pueden ser utilizados para desarrollar todos los atributos esenciales de la Atención Primaria. Conclusiones: El uso de la e-Salud en la Atención Primaria potencial para mejorar la salud y reducir costes. Una política nacional clara y específica, un amplio debate sobre la regulación y una estrecha relación entre profesionales de salud y desarrolladores de tecnología de la información se requieren para ofrecer eSalud eficaz y en línea a los atributos esenciales de la Atención Primaria.

Cite as: Landsberg GAP. e-Health and Primary Care in Brazil: concepts, correlations and trends. Rev Bras Med Fam Comunidade. 2016;11(38):1-9. http://dx.doi.org/10.5712/rbmfc11(38)1234

\section{Keywords:}

Primary Health Care

Telemedicine

Medical Informatics

Electronic Health Records

Mobile Applications

Palavras-chave:

Atenção Primária à Saúde

Telemedicina

Informática Médica

Registros Eletrônicos

de Saúde

Aplicativos Móveis

Palabras clave: Atención Primaria de Salud Telemedicina Informática Médica Registros Electrónicos de Salud Aplicaciones Móviles

Funding:

none declared.

Ethical approval: not necessary.

Conflito de interesses: none declared.

Provenance and peer review: externally reviewed.

Received: 27/10/2015.

Accepted: 25/04/2016. 


\section{Introduction}

\section{Primary Health Care}

Primary Care is the "level of a health service system that provides entry into the system for all new needs and problems, provides person-focused (not disease-oriented) care over time, provides care for all but very uncommon or unusual conditions, and co-ordinates or integrates care provided elsewhere by others". ${ }^{1}$

Primary Care has been recognized as a basis for an efficient health system, regardless of the country's development stage. Current evidence clearly shows that nations with strengthened primary care have better health indicators. ${ }^{2,3}$

It has been 20 years since Brazilian's Ministry of Health launched the Family Health Program (1994) as a plan to provide Primary Health Care in the context of the National Health System - known as Sistema Único de Saúde (SUS). Since then, the program "has grown in a progressive and sustainable way, bringing back Primary Care and Family Medicine to the center of discussions on public health". With increasing coverage over the national territory, Family Health Program is now called "Family Health Strategy" and reaches more than $50 \%$ of population. ${ }^{4}$

Several studies were published evaluating Family Health Strategy's performance and its impact on health indicators, with remarkable results. The current evidence supports that improving core attributes of primary care results in fewer hospitalizations, less visits for the same health problem, fewer complementary tests, improved preventive services, higher adherence to treatments, higher patient satisfaction and better health indicators, such as child mortality, cardiovascular mortality and many others. ${ }^{5,6}$ The Ministry of Health, however, still faces the challenge of taking Primary Care to $38 \%$ of the population who is still without access. ${ }^{7}$

Despite all the benefits demonstrated by international literature and by Brazilian public Family Health Strategy, the same position was not adopted in the private health sector. Recently, a new shift towards Primary Care in the private sector has been observed, with isolated initiatives yet not representing the mainstream of healthcare. Foreign capital is also arriving to healthcare business in the country, with potential to change vectors of force..$^{8-12}$

\section{e-Health}

World Health Organization defines e-Health as "the cost-effective and secure use of information and communication technologies in support of health and health-related fields, including health-care services, health surveillance, health literature, and health education". ${ }^{13}$

It's been 10 years since the WHA58.28 World Health Organization resolution, which set an international policy on e-Health and stressed the "potential impact that advances in information and communication technologies could have on healthcare delivery, public health, research and health-related activities for the benefit of both low- and high-income countries". In the year before, Brazilian Ministry of Health had published a visionary document establishing a national strategy on health information technology. ${ }^{14}$ 
Despite of the great advance in information technology, causing in deep chances in human behavior, its applications in healthcare are still not widely available. Some successful examples were reported, but medical practice in Brazil remains practically unaffected and useful resources are still not being used..$^{15}$

\section{Enhancing Primary Care with e-Health}

\section{Primary Care Core Attributes}

Primary Care's concept can be better understood by its four core attributes: first-contact access, longitudinality, comprehensiveness and care coordination.

\section{First-contact access}

The first contact is important feature for proper development of Primary Care. It is based on the idea that there should be a place or specific provider of health care, acting as a point of input to the system. People should first seek this provider whenever they feel sick.

Generically, facilitated access to health services improves continuity of the relationship between the health professional and the person seeking care, and how much easier the person's access to primary care, the greater the potential to reduce preventable diseases and avoid unnecessary expenses.

\section{Longidudinality of care}

The very essence of longitudinally is a personal relationship established between the patient and his doctor or the health professional team. Such relationship, developed through the years, helps increase the understanding of the individual context, his health condition and his unique perception oh health and sickness. This knowledge improves doctor's clinical judgment and help them making more efficient actions. Longitudinally is associated to greater patient satisfaction and a reduction on hospitalizations and care costs.

\section{Comprehensive care}

Comprehensiveness may be understood as $(\mathrm{A})$ a set of the needs of health programs and services that a given patient requires; or (B) a feature of the organization of services, aimed at health promotion, disease prevention, cure and rehabilitation as well. To provide a comprehensive care means to be able to manage a broad range of people's health needs.

\section{Coordinated care}

Coordination of care is related to the availability of information about the person, its history, its problems, the actions taken and the resources available - provided by information systems and information transmission and communication mechanisms. It is also the effective use of such information, possibility the easy obtaining them by means records readily available for recognition of prior information by referral mechanisms and written recommendations to patients about their problems of health and the services provided. ${ }^{16}$ 


\section{e-Health resources}

There's no formal criteria to classify e-Health resources, but many branches are known and already operating: electronic health records (EHR), telemedicine, telemonitoring, decision support systems, electronic prescribing tools, internet-based services, mobile health and others. All those resources may help health professionals and managers to reinforce the core principles of Primary Health Care. Further discussion is needed to propose a classification for e-health resources and a common vocabulary is crucial to evaluate those resources and its potential benefits or risks to patients. Nevertheless, there are several MeSH terms that can be used to search for evidence in literature (Table 1).

Table 1. Some e-Health related MeSH Terms.

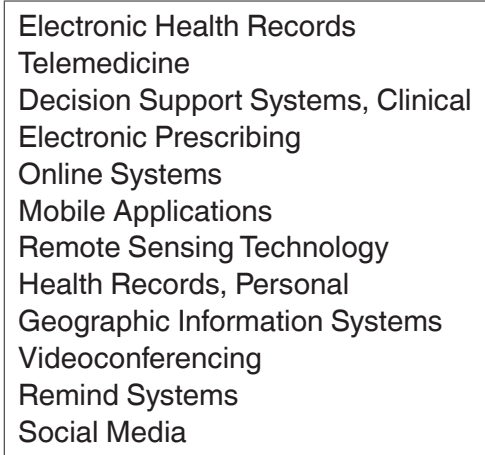

Source: MeSH database, 2015.

\section{"e-Primary Care"}

\section{E-Health resources (Table 2) can support the four core attributes of Primary Care (Table 1). ${ }^{17}$}

Table 2. Core attributes of Primary Health Care and related e-Health resources.

\begin{tabular}{|c|c|}
\hline Primary Care Atribute & e-Health resource \\
\hline First-contact access & $\begin{array}{l}\text { EHR (POMR/ICPC-2) } \\
\text { Chat tools } \\
\text { Online appointments } \\
\text { Appointment reminders } \\
\text { Telehealth } \\
\text { ePrescription }\end{array}$ \\
\hline Longitudinality & $\begin{array}{l}\text { EHR (POMR/ICPC-2) } \\
\text { Predictive Big Data } \\
\text { Personal health record } \\
\text { Telemonitoring }\end{array}$ \\
\hline Compreensiveness & $\begin{array}{l}\text { EHR (POMR/ICPC-2) } \\
\text { mHealth } \\
\text { Social media } \\
\text { Gamification } \\
\text { Decision support tools } \\
\text { Prevention apps } \\
\text { Predictive Big Data } \\
\text { Health program apps } \\
\text { Telehealth } \\
\text { Geographic Information Systems }\end{array}$ \\
\hline Coordinated care & $\begin{array}{l}\text { EHR (POMR/ICPC-2) } \\
\text { Telehealth } \\
\text { Personal health record }\end{array}$ \\
\hline
\end{tabular}


First-contact access can be enhanced by many e-Health resources. Chat tools can improve access to health services, connecting patients to doctors and nurses. Online scheduling systems can make consultations easier to schedule. Electronic reminders may reduce missing appointments and if less visits are missed, then more time is available and first-contact access is facilitated. E-prescription processes may reduce same-day appointments, eventually taking from office chronic patients, when they feel good and only need to renew their prescriptions, in a merely administrative consultation. In some place in Brazil, administrative activity represents almost $20 \%$ of all visits. Taking it off from the pipeline of the family physician may save some precious time. Using Problem Oriented Medical Records (POMR) may have the same effect, because helps doctors to spend less time recording data into EHR. Those are some examples of how technology can enhance first-contact access.

Long term care is benefited by technology as well. Caring for a patient over a large period of time generates large amounts of information, which is useless unless you can reach it. Primary care doctors "manages simultaneously both acute and chronic health problems of individual patients. They also deal with illness which presents in an undifferentiated way at an early stage in its development, which may require urgent intervention". ${ }^{18}$ That's why having a powerful EHR is so important - it delivers to doctor information they can use to make better decisions about one's health.

Comprehensiveness of care may also be improved with information technology. Many mobile apps available can be used to offer a different range of health services and provide preventive care. Diabetic patients, for example, can count on many mobile apps with different purposes: diet control, glycemic tracking, insulin application site manager, and hints for caring at diabetic feet, diabetic social communities and many others. Using applications with gamification tools may support rehabilitation and lifestyle modification. Mobile surveys may help detect and deal with individual's needs. Predictive big data may provide new ways of detecting patients at risk and allow opportune interventions. Clinical decision support and digital health programs may increase compliance to guidelines, by doctors and patients. Telehealth services may increase access to secondary care, increasing Primary Care resolutivity. Geographic information provided by mobile apps may help health operators to find new ways of dealing with community demand and planning provision of comprehensive care.

Finally, coordinated care may be the most benefited attribute of Primary Care, since it is highly related to information management. Interoperable EHR's can the great sponsors of a coordinated care, dealing with health information coming from multiple sources and delivering it to care providers in an efficient way. Telehealth services, telemonitoring systems and remote wearable sensors will create new medical information that can be integrated do health records, increasing professionals, increasing professionals access to patient's health information.

\section{International Classification of Primary Care}

The second version of the International Classification of Primary Care (ICPC-2) is part of the World Health Organization (WHO) classification family. It "classifies patient data and clinical activity in the domains of General/Family Practice and primary care, taking into account the frequency distribution of problems seen in these domains". There is, it was designed not only to classify health problems and general health care interventions often seen in this context but also to organize content in Primary Care domain. ${ }^{19}$ 
Therefore, any information technology system designed for the Primary Care setting, whether an EHR or other, should use ICPC-2. It is the classification system most appropriate for this level of care and provides a simple and effective method to record: (1) the reasons why patients seek medical attention (2) the most frequent diagnoses presented (3) what are the resultant procedures recommended by the professionals for that problem. ${ }^{19}$

ICPC-2 is ideally used on a episode of care structure, defined as "all services provided to a patient with a medical problem within a specific period of time across a continuum of care in an integrated health care system". Therefore, an episode of care may be represented by one or more consultations, and sometimes may never end (like in some chronic diseases, such as diabetes or hypertension). ${ }^{20}$

The registration of clinical information using ICPC brings many benefits - especially for the care coordination. It makes possible to represent properly the most common problems observed in the Primary Care setting. It also presents clinical data in way that other health professionals (like nurses and nutritionists) can easily access and understand.

The episode of care model also allows linking together all consultations, tests and referrals related to a specific health problem. Therefore, it makes possible to make a full analysis of all costs related to a specific health problem over a defined period. This creates opportunity for new models of costs calculation and payment policies. ${ }^{21,22}$

Additionally, the ICPC logic of patient-centeredness and representation of the most common problems in primary care can be used in other systems beyond the EHR, such as health applications, personal health records, teleconsulting systems or even medical content websites for the general population - since the classification covers the symptoms and health problems most frequently observed in the primary health care scenario.

\section{Trends in Brazil}

Brazilian Primary Care faces an peculiar situation: around 40 million people pay for a private health plan - with restricted or no access to Primary Care. New models are being tested and some initiatives are underway, but still do not represent mainstream. Foreign capital is being invested on healthcare business, coming from countries where the figure of the family doctor/general practitioner is more widespread and health technology is in a more developed stage..$^{10,23}$

Additionally, investment in e-Health is increasing all over the world and Brazil is considered a strong potential market, since it has good information and telecommunication infrastructure and the health information technology sector is at an early stage. Therefore, much technology may be incorporated to the health sector and to Primary Care over the next years, as is being observed in developed countries. ${ }^{24-26}$ Health IT sector has traditionally focused on hospital medical records, driven by payment systems, and may be not prepared to attend Primary Care needs. There are gaps in current EHR functionalities and enhancements are needed to better support primary care. ${ }^{27}$

There is also a large discussion whether HER in fact help doctors or increase burden of work. Literature has shown that HER adoption has led to advances in terms of documenting patient data and improving prescriptions, however most of the systems fail to capture clinical data in a structured way - the 
most appropriate to measure indicators and help improve care delivery. There are also challenges regarding sharing data and providing decision support during patient care, or allowing population health monitoring or management. ${ }^{28}$ The current scenario, therefore, offers large opportunities for EHR improvements, since in about half of the offices in Brazil doctors are still using paper-based health record. ${ }^{24}$

Moreover, medical information has outreached the EHR and there are new technological resources to be considered - like mobile health. There are more than 100,000 health apps available and the number is constantly growing. These applications may bring huge benefits to public health by $(A)$ improving the quality of care and reducing medical errors, (B) monitoring chronic conditions and reducing spending with physician office visits and hospitalizations, and (C) broadening access to care, specially in less developed countries. There are some mobile health initiatives reported in Brazil, specially for health surveys, surveillance, patient records and monitoring. ${ }^{29-31}$

Telemedicine services also meet expanding but the sector is heavily regulated and Brazilian law restricts a broader use of technology. Although teleconsultation can help overcome physical barriers in the access to health care, straight patient-doctor teleconsultations are not allowed in the country - only mediated by another health professional. ${ }^{32}$

\section{Conclusion}

Brazilian Health system will probably face some changes over the next years: increasing e-Health utilization and a expansion of Primary Care, specially in private sector. This may bring deep changes in the way healthcare will be delivered - raising concerns about how it will affect patients and professionals.

Great opportunities are available for health plan operators and government health managers to reduce their costs by improving health of their beneficiaries. Investing in safe and cost-effective e-Health connected to Primary Health Care is an obvious path to reach that.

In other to face challenges and take advantages from the use of eHealth in Primary Care, an updated clear national policy on Health information Technology for Primary Care, a more interactive relationship between Primary Care professionals and health IT developers and a broad discussion over current regulation rules for telemedicine are needed.

\section{References}

1. Starfield B. Primary Care: balancing health needs, services and technology. 2nd ed. New York: Oxford University Press; 1998. p.8-9.

2. World Health Organization. Report of the International Conference on Primary Care. Alma-Ata, USSR, 6-12 September. Geneva: World Health Organization; 1978.

3. Starfield B, Shi L, Macinko J. Contribution of primary care to health systems and health. Milbank Q. 2005;83(3):457-502. PMID: 16202000 DOI: http://dx.doi.org/10.1111/j.1468-0009.2005.00409.x

4. Sampaio LFR, Mendonça CS, Lermer Junior N. Atenção Primária à Saúde no Brasil. In: Gusso G, Lopes JMC, Org. Tratado de Medicina de Família e Comunidade. 1a ed. Porto Alegre: Artmed; 2012. p.29-39.

5. Harris M. Integrating primary care and public health: learning from the Brazilian way. London J Prim Care (Abingdon). 2012;4(2):126-32. DOI: http://dx.doi.org/10.1080/17571472.2012.11493350

6. Rasella D, Harhay MO, Pamponet ML, Aquino R, Barreto ML. Impact of primary health care on mortality from heart and cerebrovascular diseases in Brazil: a nationwide analysis of longitudinal data. BMJ. 2014;349:94014. PMID: 24994807 DOI: http://dx.doi.org/10.1136/bmj.g4014 
7. Macinko J, Harris MJ. Brazil's family health strategy--delivering community-based primary care in a universal health system. N Engl J Med. 2015;372(23):2177-81. DOI: http://dx.doi.org/10.1056/NEJMp1501140

8. Unimed Belo Horizonte [website on internet]. Unimed Pleno. [accessed 2014 Dec 22]. Available from: http://www.portal.unimedbh.com.br/wps/portal/inicio/home/planos/planos_para_sua_empresa/unimed_pleno

9. Fundação Unimed [website on internet]. Pós-graduação em Atenção Primária à Saúde. [accessed 2014 Dec 22]. Available from: http://www.fundacaounimed.org.br/pos-graduacao/medicina-saude/atencao-primaria-a-saude/Paginas/default.aspx

10. Jornal O Dia [homepage on internet]. Planos de saúde adotam sistema de medicina familiar [accessed 2014 Dec 22]. Available from: http://odia.ig.com.br/noticia/economia/2014-07-29/planos-de-saude-adotam-sistema-de-medicina-familiar.html

11. Carneiro Junior N, Nascimento VB, Costa IMC. Relação entre Público e Privado na Atenção Primária à Saúde: considerações preliminares. Saúde Soc. 2011;20(4):971-9.

12. G1 Notícias. [website on internet]. Americana United Health compra Amil por 6,49 bilhoes. [accessed 2014 Dec 22]. Available from: http://g1.globo.com/economia/negocios/noticia/2012/10/americana-unitedhealth-compra-amil-por-r-649-bilhoes.html

13. World Health Organization. Resolution WHA58.28. eHealth. Fifty-eighth World Health Assembly, Geneva, 16-25 May 2005. Annex. Resolutions and decisions [Internet]. Geneva:World Health Organization; 2005 (WHA58/2005/REC/1). [accessed 2014 Dec 22]. Available from: http://apps.who.int/gb/ebwha/pdf_files/WHA58-REC1/english/A58_2005_REC1-en.pdf

14. Brasil. Ministério da Saúde. Secretaria Executiva. Política Nacional de Informação e Informática em Saúde: proposta versão 2.0 (Inclui deliberações da 12a. Conferência Nacional de Saúde). Brasília; 2004. [accessed 2014 Dec 22]. Available from: bvsms.saude.gov.br/bvs/publicacoes/Politica_Informacao_Saude.pdf

15. Alkmim MB, Figueira RM, Marcolino MS, Cardoso CS, Pena de Abreu M, Cunha LR, et al. Improving patient access to specialized health care: the Telehealth Network of Minas Gerais, Brazil. Bull World Health Organ. 2012;90(5):373-8. DOI: http://dx.doi.org/10.2471/BLT.11.099408

16. Landsberg G, Siqueira IOC, Pereira RPA. Primária: o essencial da atenção primária à saúde. Caratinga: FUNEC, 2012. 186p.

17. Landsberg G, lanelli MR, Brioschi JA, Cardoso AMJ, Saleme CS. Oportunidades e Desafios Relacionados ao Telemonitoramento: Um Relato de Experiência. In: XIV Congresso Brasileiro de Informática em Saúde, 2014. São Paulo: CBIS; 2014.

18. Evans P. The European Definition of General Practice/Family Medicine. London: Wonca Europe; 2002.

19. World Organization of National Colleges Academies and Academic Associations of General Practitioners/Family Physicians. Classificação Internacional de Atenção Primária (CIAP 2) - Comitê Internacional de Classificação da WONCA. Florianópolis: Sociedade Brasileira de Medicina de Família e Comunidade; 2009.

20. Gusso G; Landsberg G, Pinto CMF. Prontuário eletrônico e uso de sistema de classificação na Atenção Primária à Saúde. In: Gusso G, Lopes JMC, Org. Tratado de Medicina de Família e Comunidade. 1ed. Porto Alegre: Artmed; 2012. p.337-45.

21. Medical Dictionary for the Health Professions and Nursing. S.v. "episode of care." [internet homepage] [accessed 2014 Dec 20]. Available from: http://medical-dictionary.thefreedictionary.com/episode+of+care

22. Hussey P, Sorbero M, Mehrotra A, Liu H, Damberg C. Using Episodes of Care as a Basis for Performance Measurement and Payment: Moving from Concept to Practice. Health Aff (Millwood). 2009;28(5):1406-17. DOI: http://dx.doi.org/10.1377/hlthaff.28.5.1406

23. Paim J, Travassos C, Almeida C, Bahia L, Macinko J. The Brazilian health system: history, advances, and challenges. Lancet. 2011;377(9779):1778-97. PMID: 21561655 DOI: http://dx.doi.org/10.1016/S0140-6736(11)60054-8

24. CETIC [website on internet]. Pesquisa TIC Saúde [accessed 2014 Dec 22]. Available from: http://www.cetic.br/pesquisa/saude/

25. U.S. Department of Commerce [website on internet], 2015 [accessed 2016 Jan 14]. Available from: http://trade.gov/topmarkets/pdf/Health_IT_Top_Markets_Report.pdf

26. Schoen C, Osborn R, Squires D, Doty M, Rasmussen P, Pierson R, et al. A survey of primary care doctors in ten countries shows progress in use of health information technology, less in other areas. Health Aff (Millwood). 2012;31(12):2805-16. DOI: http://dx.doi.org/10.1377/hlthaff.2012.0884 
27. Krist AH, Beasley JW, Crosson JC, Kibbe DC, Klinkman MS, Lehmann CU, et al. Electronic health record functionality needed to better support primary care. J Am Med Inform Assoc.2014;21 (5):764-71. DOl:http://dx.doi.org/10.1136/amiajnl-2013-002229

28. Phillips RL Jr, Bazemore AW, DeVoe JE, Weida TJ, Krist AH, Dulin MF, et al. A Family Medicine Health Technology Strategy for Achieving the Triple Aim for US Health Care. Fam Med. 2015;47(8):628-35.

29. Cortez NG, Cohen IG, Kesselheim AS. FDA regulation of mobile health technologies. N Engl J Med. 2014;371(4):372-9. PMID: 25054722 DOI: http://dx.doi.org/10.1056/NEJMhle1403384

30. Kahn JG, Yang JS, Kahn JS. 'Mobile' health needs and opportunities in developing countries. Health Aff (Millwood). 2010;29(2):252-8. DOI: http://dx.doi.org/10.1377/hlthaff.2009.0965

31. Iwaya LH, Gomes MA, Simplício MA, Carvalho TC, Dominicini CK, Sakuragui RR, et al. Mobile health in emerging countries: a survey of research initiatives in Brazil. Int J Med Inform. 2013;82(5):283-98. DOI:http://dx.doi.org/10.1016/j.jimedinf.2013.01.003

32. Brasil. Conselho Federal de Medicina. Resolução no 1931, de 24 de setembro de 2009. Aprova o código de ética médica. D Of União. 24 set 2009;(183, seção I):90-2. Retificações em: D Of União. 13 out 2009;(195, seção I):173. [accessed 2016 May 24]. Available from: www.in.gov.br 